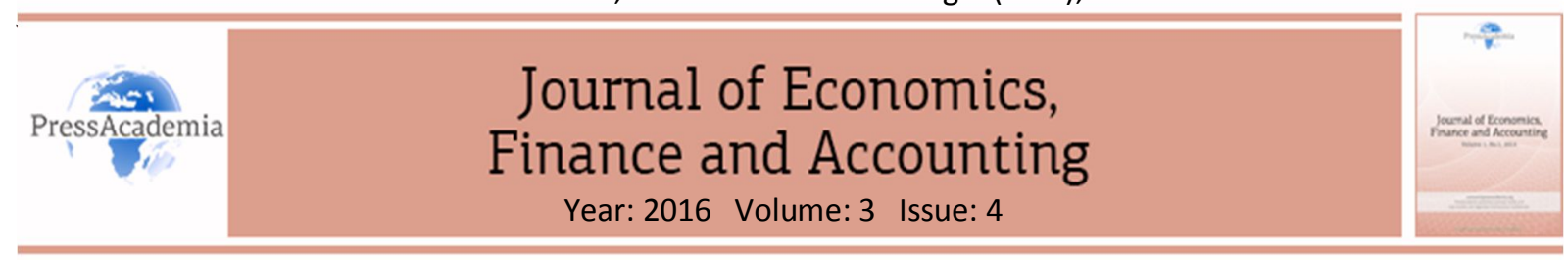

\title{
THE IMPACT ON EARNINGS QUALITY AUDIT AND INTERNAL CONTROL WEAKNESSES IN COMPANIES LISTED ON THE TEHRAN STOCK EXCHANGE
}

\section{DOI: $10.17261 /$ Pressacademia.2016.344}

\author{
Mohammad Esmaeili ${ }^{1}$, Mahmoud Abolpour ${ }^{2 *}$, Hashem Valipour ${ }^{3}$ \\ ${ }^{1}$ Firouzabad Islamic Azad University, mohammad.ostan@gmail.com \\ ${ }^{2}$ Firouzabad Islamic Azad University, mofrad1333@gmail.com \\ ${ }^{3}$ Firouzabad Islamic Azad University, h.valipour@gmail.com
}

\begin{abstract}
Forecast accounting earnings and economic change has long time that has attracted investor's interest, managers, financial analysts, researchers and creditors. And is counted the most important source of information for investors, creditors and other users, especially on the stock exchange. Therefore, this study examines the impact of earning quality audit and internal control weaknesses in companies listed on the Tehran Stock Exchange. The target population included all companies listed in Tehran Stock Exchange during the period of 20082014, respectively. For statistical analysis used the descriptive statistics and inferential statistics and regression. We used the $\mathrm{F}$ index at the error level of $5 \%$ and P-Value, for the Significance test of independent variables used the T index $90 \%, 95 \%$ and $99 \%$ to evaluate the significance of regression models. The results showed that auditor industry specialization have direct impacts with profit and earnings quality will be increased significantly. Also, the results showed that auditor industry specialization has an impact on earnings quality and as well as weaknesses in internal controls effect on earnings quality and auditor industry specialization, the impact on earnings quality moderated weak internal controls.
\end{abstract}

Keywords: Earnings quality, Tehran, Stock Exchange, weak internal controls.

JEL Classification: C58

\section{INTRODUCTION}

Main factors of fundamental changes in economic environment of Iran include generalization of economic firms' ownership, financing through public and private partnership and privatization of governmental departments and economic firms. In such circumstances, transparency and high quality of financial information is very important because it is basis for optimal economic decisions of investors, creditors and generally, information users. In fact, profit management occurs when managers express their judgment on financial reporting and how to register financial reports, as which changes in content of financial reports mislead some shareholders about economic performance of company(Jamei and Khedri., 2016). The link between accounting information and the cost of capital of firms is one of the most fundamental issues in accounting that standard setters frequently refer to it, and in the context of financial information, the end result is that better disclosure results in a lower cost of capital (Lambert et al., 2007; Foster., 2003). A fundamental role of accounting information in financial markets is to serve as a basis for capital allocation. If investors differ in their ability to process earnings related information, then poor earnings quality can result in differentially informed investors and thereby exacerbate the information asymmetry in financial markets (Bhattacharya et al., 2013; Diamond and Verrecchia 1991; Kim and Verrecchia 1994). Consequently, the determinants and consequences of earnings quality are of interest to investors, managers, regulators, and standard-setters. A notion implicit in this remark is that regulators and standard-setters view the reduction in information asymmetry to be an important benefit 
of improved earnings quality. Using an accruals-based measure of earnings quality and a market microstructure based measure of information asymmetry, we test for the association between earnings quality and internal control weaknesses for a large sample of companies listed on the Tehran Stock Exchange over the period 20082014.

\section{LITERATURE REVIEW}

Several studies have been conducted to fine ground on earnings quality audit and accounting information in companies. That here refers to several of these studies. Rajgopal and Venkatachalam (2011) show that reduced earnings quality is associated with increased company-level volatility. Hassan (2013) examined monitoring characteristics and financial reporting quality of the Nigerian listed manufacturing firms. They Using 32 firmsyears longitudinal paneled of 160 observations, panel OLS is estimated and controlled for fixed/random effects. They result shows a significant positive relationship between monitoring characteristics and financial reporting quality. The Hausman specification test shows that the panel result after controlling for random, best suits the population as the fixed effect hypothesis was rejected by the Wald/Ch2 test. Febriela and Sylvia (2014) are conducted research with aims to examine the relationship between dividend payment and earnings quality. This study examines only the manufacturing firms listed on the Indonesia Stock Exchange. Further study based on different industries and/or different emerging markets is needed before generalizing results. The authors examine four dividend features: dividend-paying status, dividend size, dividend changes, and dividend persistence. The samples consist of 90 firms from the manufacturing industry in the years 2005-2009. Multiple regression is used for testing hypotheses. The results show that dividend-paying status, dividend increase, and persistence in dividend payment have significant positive association with earnings quality. However, the authors do not find evidence that larger dividend size is an indicator of higher earnings quality. Overall, the results show that dividend-paying status, increase in dividend size, and persistence in dividend payment are indicators or signals of higher earnings quality. Poorheidari and Borhaninejad (2012) evaluated the effect of characteristics of firms' strategic principles on tax management in firms listed in Tehran Stock Exchange. In their research, characteristics of company's strategic principles include board size, board composition, CEO duality and size of audit firm. Their results suggest a negative relationship between board composition and size of audit firm with tax management. Tong and Miao (2011) also examine the relationship between dividend and earnings quality. They use only three features of dividends (dividend-paying status, dividend size, and dividend persistence). Hanlon et al. (2007) show that investors can better predict future earnings if companies distribute dividends (i.e. dividend has predictive value). Tong and Miao (2011) also examine the relationship between dividend payment and earnings quality. Companies that distribute dividends have higher earnings quality than companies that do not distribute dividends. A larger size of dividend and dividend persistence also indicates higher earnings quality. Using samples of companies that the SEC accused of committing financial reporting fraud, Caskey and Hanlon (2005) find that fraudulent companies did not pay a dividend and had a smaller increase of dividends than other companies. Chen et al. (2007) use the accruals quality (AQ) based on the Dechow and Dichev (2002) model as a proxy of information risk. They conclude that firms that distribute dividends and increase dividend size have lower information risk (more accurate earnings information), smaller analyst forecast dispersion, and lower future stock returns volatility. Investors treat risk-related information (the accuracy of information in the financial statements) as a priced risk factor. This finding indicates that dividend distribution is an indicator of earnings quality. Our study contributes to the extant literature by focusing on Tehran, one of the emerging markets. Tehran is an emerging economy whose capital market has undergone significant regulatory reforms and has an institutional environment that differs from other countries; such differences have implications for dividend policy and earnings quality. Following this stream of research, our study examines whether internal control weaknesses is a companies listed on the Stock Exchange of higher earnings quality in Tehran.

Research Hypotheses - In this research, we seek to examine the internal control weaknesses is a companies listed on the Stock Exchange of higher earnings quality in Tehran, which the following hypotheses have been developed based on it.

$\mathrm{H} 1$ : There is a significant relationship between auditor industry specialization and quality of earnings.

$\mathrm{H} 2$ : There is a significant relationship between the weakness of internal controls and the earnings quality. 
H3: There is a significant relationship between Auditor industry specialization and internal controls weaknesses and the earnings quality.

\section{DATA AND METHODOLOGY}

\subsection{Population, Statistical Sampling and Survey Period}

The study population consisted of all listed companies on the Stock Exchange Tehran. Due to the vast size of its population and the unique challenges and there is also some inconsistency among community members in relation to data Study, the following criteria for selection of statistical samples and placed they statistical sample Systematic elimination method selected. To test the hypotheses of this research, the researcher made questionnaire was used. Between financial executives listed companies in Tehran Stock Exchange has been distributed. Study period is years 2008-2014.

\subsection{Method of Research}

In the research, we have achieved the required financial data from the audited financial statements and notes of the studied companies and the provided CDs by Tehran Stock Exchange reports (annual financial statements and explanatory notes) collected and internet sites of intraday stock exchange statistics to calculate variables in a database. After collecting and categorizing data, the researcher should begin the next stage of research process known as data analysis stage. In this stage, the researcher investigates data to test and evaluate hypothesis. In this study, sampling was conducted using systematic elimination. Firstly, the research samples are selected using list of the accepted companies in Tehran Stock Exchange from beginning of 2008 until the end of 2014. Then the research variables will be collected and calculated for the considered companies in each year. After collecting the required data, Excel, SPSS 20 and Eviews 8 software were used to analyze data. In the next step, analytical data was evaluated descriptively using statistical methods. Then the research hypotheses were tested using Correlation test, Significance test of independent variables, multiple regression technique and the relationship between independent and control variables with the dependent variable has been investigated.

\subsection{Research Model}

This hypothesis is estimated by panel data method from model (1, 2 and 3 ) and if cash flow variable coefficient in confidence level of $95 \%$ is significant, it will be confirmed. To test the hypotheses used in the following models:

$$
A D A C_{t}=\beta_{0}+\beta_{1} \text { Special }_{t}+\beta_{2} L E V_{i t}+\beta_{3} M B_{i t}+\varepsilon_{i t}
$$

Table 1: The First Model Variables

\begin{tabular}{ccc}
\hline Type & Symbol & Definition \\
\hline Dependent & $A D A C$ & The absolute value of \\
Independent & discretionary accruals \\
control & Special & Auditor industry specialization \\
& $M B V$ & Financial Leverage \\
& $M B$ & The ratio of book value to \\
& market \\
\hline
\end{tabular}

(2)

$$
A Q_{i t}=\beta_{0}+\beta_{1} I C W_{i t}+\beta_{2} I C W \times \text { Special }+\beta_{3} L E V_{i t}+\beta_{4} M B_{i t}+\varepsilon_{i t}
$$

Table 2: The Secound Model Variables

\begin{tabular}{ccc}
\hline Type & Symbol & Definition \\
\hline Dependent & $A Q$ & Quality accruals \\
Independent & $I C W$ & Internal control weaknesses \\
Control & $L E V$ & Financial Leverage \\
& $M B$ & The ratio of book value to \\
& market \\
\hline
\end{tabular}




$$
A Q_{i t}=\beta_{0}+\beta_{1} \text { ExpeitAudit }_{i t}+\beta_{2} I C W_{i t}+\beta_{3} \text { Expeit }^{*} I C W_{i t}+\beta_{4} L E V_{i t}+\beta_{5} M B_{i t}+\varepsilon_{i t}
$$

Table 3: The Third Model Variables

\begin{tabular}{ccc}
\hline Type & Symbol & Definition \\
\hline Dependent & $A Q$ & Quality accruals \\
Independent & $I C W$ & Internal control weaknesses \\
Control & Expeit Audit & Auditor features \\
& $L E V$ & Financial Leverage \\
& $M B$ & The ratio of book value to \\
& market \\
\hline
\end{tabular}

In this research, earnings quality is considered as the dependent variable. In this study, for the calculation of earnings quality to comply with Francis et al (2004) are used of quality metrics profit based on accounting information and metrics based on market data. To calculate the accruals quality on working capital was used Dechow and Dichev (2002) model:

$$
\Delta W C_{t}=b_{0}+b_{1} C F O_{t-1}+b_{2} C F O_{t}+b_{3} C F O_{t+1}+u_{t}
$$

In above model;

$\Delta W C_{t}=$ Indicating a change in working capital $t$ year over the previous year, $C F O_{t-1}=$ Operating cash flow of $t-1, C F O_{t}=$ Operating cash flow of $t, C F O_{t+1}=$ Operating cash flow of $t+1, u_{t}=$ Residual error of the model for $t$

This model has a standard error to estimate total of accruals and inverse of earnings quality. The independent variables in this model, cash flow obtained from operating activities for a period of past, current and future periods is that the data obtained from the cash flow statement and the dependent variable working capital accruals. Accruals working capital is calculated as follows:

$$
\Delta W C_{t}=\Delta C A_{t}-\Delta C L_{t}-\Delta \operatorname{Cash}_{t}+\Delta D e b t_{t}
$$

In above model;

$\Delta W C_{t}=$ Change in working capital $t$ year comparison to last year, $\Delta C A_{t}=$ Change in current assets $t$ year comparison to last year, $\Delta C L_{t}=$ Change in current liabilities $t$ year comparison to last year, $\Delta \operatorname{Cash}_{t}=$ Change in cash $t$ year comparison to last year, $\Delta D e b t_{t}=$ Change in current portion of financial liabilities $t$ year comparison to last year (All variables in the model and Dechow and Dichev (2002) Based on adjusted total assets).

Accruals quality standards, the residual model error and standard deviation lower this number indicates a higher quality of earnings. In multivariate linear regression following equation that describes society is that has a three-dimensional space:

$$
y=\alpha+\beta_{1} X_{1}+\beta_{2} X_{2}+\varepsilon_{0}
$$

In this equation, $y$ the dependent variable, $x$ the independent variable and $\beta_{l}, \alpha$ is a fixed values of the regression line slope and $\mathcal{E}$. the effect of other factors in the equation, respectively.

The correlation coefficient has different scenarios according to the type of regression graphs and scatter plot, and has always been defined as between 1, -1 and whatever absolute value of the correlation coefficient is closer to number one can say that will be less the difference between the predicted values with the actual values, means that regression equation has a fewer errors and greater reliability. The correlation coefficient was calculated as follows:

$$
r=\frac{n \sum X_{i} Y_{i}-\left(\sum X_{i}\right)\left(\sum Y_{i}\right)}{\sqrt{\left[n \sum X_{i}^{2}-\left(\sum X_{i}\right)^{2}\right]\left[n \sum Y_{i}^{2}-\left(\sum Y_{i}\right)^{2}\right]}}
$$


To estimate the two Variables and multivariate linear regression models were used method of least normal squares is shown briefly by OLS. To solve the problems such as residuals autocorrelation and heteroscedasticity was used the method of least squares (GLS) (Shirinbakhsh and Khansari., 2005). To evaluate the significance of regression models and relationships test between independent variables and the dependent variable was using F index.

$$
F=\frac{\frac{R^{2}}{(K-1)}}{\frac{\left(1-R^{2}\right)}{(n-K)}}
$$

To evaluate the significance of the independent variables coefficients used the $t$ index:

$$
\begin{aligned}
t & =\frac{\beta^{\wedge}}{S e_{\beta}} \\
\sigma^{\wedge} & =\frac{\sum e^{2}}{\mathrm{n}-\mathrm{k}}
\end{aligned}
$$

$\hat{\beta}=$ The estimated coefficients, $\mathrm{Se}_{\beta}=$ Standard deviation of coefficient estimates, $\mathrm{e}^{2}=$ the square of the difference between actual observations and estimates, $n=$ Value observations, $k=$ the number of parameters.

\section{FINDINGS AND DISCUSSIONS}

Descriptive Statistics: At first we examine descriptive statistics. Descriptive statistics are as follows:

Table 4: Descriptive Statistics of Research Variables

\begin{tabular}{lccccc}
\hline \multicolumn{1}{c}{ Variable } & mean & median & standard deviation & minimum & maximum \\
\hline ADAC & 71.476 & 33.315 & 98.930 & 0.000 & 859.500 \\
Special & 0.929 & 1.000 & 0.257 & 0.000 & 1.000 \\
LEV & 0.632 & 0.620 & 0.272 & 0.090 & 3.060 \\
MB & 3.706 & 3.505 & 1.594 & -0.200 & 9.720 \\
AQ & 11.737 & 985.9 & 13.831 & -43.980 & 63.130 \\
ICW & 0.472 & 0.000 & 0.499 & 0.000 & 1.000 \\
Expeit Audit & 0.687 & 1.000 & 0.464 & 0.000 & 1.000 \\
\hline
\end{tabular}

Table 4 shows the descriptive statistics of the research variables. It can be concluded that there is a dispersive medium in all variables, this issue can be deduced of the standard deviation. Also according to the median and mean can be shown symmetric variable or not, in general all the variables has a relative symmetry.

Inferential statistics: In this section, will be discussed to test of research hypotheses are as follows:

First hypothesis: "auditor industry specialization has impact on earnings quality."

The second hypothesis is: "The internal controls weakness has impact on earnings quality."

The third hypothesis: "auditor industry specialization, internal control weaknesses has impact on earnings quality."

To test the hypothesis using panel method and regression model. In order to determine the model type and model fitted for each model and tested hypothesis related to it. The first regression model is as follows:

$$
A D A C=\beta_{0}+\beta_{1} \text { Speciqul } \beta_{2} L E V_{i t}+\beta_{3} M B_{t t}+\varepsilon_{i t}
$$


Before fitting the model, the model type was determined using Chow and Hausman test. Chow (1960) introduced a test that is used to choose between integration models and the model panel. The assumptions of this model are:

$H_{0}=$ All width of the origin are equal (Pooled Model)

$H_{1}=$ At least, is different one width of the origin to the rest (Fixed effects Model)

In this test, the null hypothesis intercept being equal coefficients and indicates in the surveyed companies. And therefore reject the null hypothesis and accepting the null hypothesis show that panel model indicates the models is integrated. Table 5 shows the results of these tests indicate reject the null hypothesis and necessity using of panels for this group of data.

Table 5: Chow Test Results

\begin{tabular}{cc}
\hline $\boldsymbol{P}-$ Value & Test statistic \\
\hline $0.0001^{* * *}$ & 107.707 \\
\hline
\end{tabular}

${ }^{* * *}$ Significance level $=5 \%$

According to Chow test confirmed the panel method, Must be selected one of the panel data estimation method and fixed effects method or random effects method. For this purpose, in the panel data was used the Hausman test statistic. The assumptions of this model are:

$H_{0}=$ Random effects model

$H_{1}=$ Fixed effects model

To determine whether using of panel data to estimate the model is efficient or not, $\mathrm{F}$ Limer test and to determine which method (fix effects and or accidental effects) is more suitable, Hasman test is used. The obtained results of these tests are presented in Table 6. Table 6 shows the results of the Hausman test, that null hypothesis is rejected and selected fixed effects model.

Table 6: Hausman Test Results

\begin{tabular}{cc}
\hline $\boldsymbol{P}-$ Value & Test statistic \\
\hline $0.0001^{\star * *}$ & 56.558 \\
\hline
\end{tabular}

\footnotetext{
${ }^{* * *}$ Significance level $=5 \%$
}

Summary model results include the coefficient of determination $r^{2}, r^{2}$ adjusted as well as standard deviation obtained for each regression model and estimation of regression coefficients and their significance test have been in the table 12. That it has been shown the coefficient of determination $r^{2}, r^{2}$ adjusted. And the coefficient of determination indicates that the changes caused by regression to allocated what percentage of the total variance. Significant test model is as follows:

$H_{0}=$ The model was not significant

$H_{1}=$ The model was significant 
Table 7: The Results of Model Fitting

\begin{tabular}{cccc}
\hline $\boldsymbol{P}-$ Value & F index & $\boldsymbol{r}^{2}$ fitting & $\boldsymbol{r}^{2}$ \\
\hline $0.0001^{\star \star \star}$ & 56.558 & 0.3235 & 0.3288
\end{tabular}

Significance level $=5 \%$

Significant test of the coefficients: Whenever, in the regression model the coefficient was not significant means that the variable in the regression model does not work on the dependent variable. Table 8 show that this test is performed using P-Value is calculated for each factor. So that if P-Value is less than $\alpha$ be a significant factor, and if $\mathrm{P}$-Value is greater than $\alpha$ the coefficient is not significant.

$\left\{H_{0}: \beta_{i}=0\right.$

$\left\{H_{1}: \beta_{i} \neq 0\right.$

Table 8: The Results of Regression Model

\begin{tabular}{cccccc}
\hline Variable & T Index & standard deviation & Value & T index & P Value \\
\hline Fixed effects model & $\beta_{0}$ & 14.099 & 79.521 & 5.640 & $0.0001^{* * *}$ \\
\hline Special & $\beta_{1}$ & 2.748 & 9.711 & 3.534 & $0.0001^{* * *}$ \\
\hline$L E V$ & $\beta_{2}$ & 10.108 & 1.031 & 0.102 & 0.919 \\
\hline$M B$ & $\beta_{3}$ & 1.737 & -0.914 & -0.527 & 0.599
\end{tabular}

${ }^{* * *}$ Significance level $=5 \%$

According to above tables' regression model is significant according to $\mathrm{F}$ statistics index and $P-$ Value . This issue indicates that the model is significant, in the following significant test was performed to determine the effect of each variable index. And model validity was determined by determination coefficient. According to the $\beta \_1$ index that is equal to 9.711 in the regression model. And statistically is significant, so the first hypothesis is accepted. Finally, Auditor industry specialization has impact on earnings quality.

\section{Autocorrelation Test (Durbin-Watson):}

One of the assumptions of the classical linear regression model argues that there is no correlation between sentences regression model. If this assumption is violated variance between the two sentences of $i$ and $j$ will be zero. There are several tests to check for any Autocorrelation between that model D-W (Durbin-Watson) test is the most common. D-W numerical value is variable between 0 and 4 ; if this statistic for model estimated to be around 2 (between 1 and 3 in the state more stringent between 1.5 and 2.5) indicates the absence of autocorrelation in the model. That in this model, the numerical these statistics is nearly 2 and will be accepted assuming no autocorrelation.

Table 9: D-W Test Results

\begin{tabular}{cc}
\hline D-W Test & Results \\
\hline 2.358 & No Autocorrelation \\
\hline
\end{tabular}

${ }^{* * *}$ Significance level = 5\% 
The second regression model is as follows:

$$
A Q_{i t}=\beta_{0}+\beta_{1} I C W_{i t}+\beta_{2} I C W \times \text { Special }+\beta_{3} L E V_{i t}+\beta_{4} M B_{i t}+\varepsilon_{i t}
$$

Before fitting the model, the model type was determined using Chow and Hausman test. Chow (1960) introduced a test that is used to choose between integration models and the model panel. The assumptions of this model are:

$H_{0}=$ All width of the origin are equal (Pooled Model)

$H_{1}=$ At least, is different one width of the origin to the rest (Fixed effects model)

Table 10 shows the results of these tests indicate reject the null hypothesis and necessity using of panels for this group of data.

Table 10: Chow Test Results

\begin{tabular}{cc}
\hline $\boldsymbol{P}-$ Value & Test statistic \\
\hline $0.0001^{* * \star}$ & 7.609 \\
\hline
\end{tabular}

\footnotetext{
${ }^{* * *}$ Significance level $=5 \%$
}

According to Chow test confirmed the panel method, Must be selected one of the panel data estimation method and fixed effects method or random effects method. For this purpose, in the panel data was used the Hausman test statistic. The assumptions of this model are:

$H_{0}=$ Random effects model

$H_{1}=$ Fixed effects model

To determine whether using of panel data to estimate the model is efficient or not, $F$ Limer test and to determine which method (fix effects and or accidental effects) is more suitable, Hasman test is used. The obtained results of these tests are presented in Table 11. Table 11 shows the results of the Hausman test, that null hypothesis is rejected and selected fixed effects model.

Table 11: Hausman Test Results

\begin{tabular}{cc}
\hline $\boldsymbol{P}-$ Value & Test statistic \\
\hline $0.0001^{\star * \star}$ & 30.439 \\
\hline
\end{tabular}

\footnotetext{
${ }^{* * *}$ Significance level $=5 \%$
}

Summary model results include the coefficient of determination $r^{2}, r^{2}$ adjusted as well as standard deviation obtained for each regression model and estimation of regression coefficients and their significance test have been in the table 12. That it has been shown the coefficient of determination $r^{2}, r^{2}$ adjusted. And the coefficient of determination indicates that the changes caused by regression to allocated what percentage of the total variance. Significant test model is as follows:

$H_{0}=$ The model was not significant

$H_{1}=$ The model was significant 
Table 12: The Results of Model Fitting

\begin{tabular}{cccc}
\hline $\boldsymbol{P}-$ Value & F index & $\boldsymbol{r}^{2}$ fitting & $\boldsymbol{r}^{2}$ \\
\hline $0.0001^{\star \star \star}$ & 56.453 & 0.4722 & 0.4770 \\
\hline
\end{tabular}

*** Significance level $=5 \%$

Whenever, in the regression model the coefficient was not significant means that the variable in the regression model does not work on the dependent variable. Table 8 show that this test is performed using P-Value is calculated for each factor. So that if $\mathrm{P}$-Value is less than $\alpha$ be a significant factor, and if $\mathrm{P}$-Value is greater than $\alpha$ the coefficient is not significant.

$$
\left\{\begin{array}{l}
H_{0}: \beta_{i}=0 \\
H_{1}: \beta_{i} \neq 0
\end{array}\right.
$$

Table 13: The Results of Regression Model

\begin{tabular}{cccccc}
\hline Variable & T Index & standard deviation & Value & T index & P Value \\
\hline Fixed effects model & $\beta_{0}$ & 1.222 & 29.623 & 24.235 & $0.0001^{* * *}$ \\
\hline$I C W$ & $\beta_{1}$ & 2.091 & -9.359 & -4.475 & $0.0001^{* * *}$ \\
\hline$I C W *$ Special & $\beta_{2}$ & 2.090 & 7.082 & 3.389 & $0.0001^{* * *}$ \\
\hline$L E V$ & $\beta_{3}$ & 1.251 & -32.402 & -25.904 & $0.0001^{* * *}$ \\
\hline$M B$ & $\beta_{4}$ & 0.216 & 1.040 & 4.827 & $0.0001^{* * *}$ \\
\hline
\end{tabular}

${ }^{* * *}$ Significance level $=5 \%$

According to above tables' regression model is significant according to $\mathrm{F}$ statistics index and $P-V a l u e$. This issue indicates that the model is significant, in the following significant test was performed to determine the effect of each variable index. And model validity was determined by determination coefficient. According to the $\beta \_1$ index that is equal to -9.359 in the regression model. And statistically is significant, so the second hypothesis is accepted. Finally, Weaknesses in internal controls has impact on earnings quality. Also, According to the $\beta \_2$ index that is equal to 7.082 in the regression model. And statistically is significant, so the third hypothesis is accepted. Finally, Auditor industry specialization and internal controls weaknesses are effective on earnings quality.

\section{Autocorrelation Test (Durbin-Watson)}

There are several tests to check for any Autocorrelation between that model D-W (Durbin-Watson) test is the most common. D-W numerical value is variable between 0 and 4; if this statistic for model estimated to be around 2 (between 1 and 3 in the state more stringent between 1.5 and 2.5) indicates the absence of autocorrelation in the model. That in this model, the numerical these statistics is nearly 2 and will be accepted assuming no autocorrelation. 
Table 14: D-W Test Results

\begin{tabular}{cc}
\hline D-W Test & Results \\
\hline 1.789 & No Autocorrelation \\
\hline
\end{tabular}

${ }^{* * *}$ Significance level $=5 \%$

The third regression model is as follows:

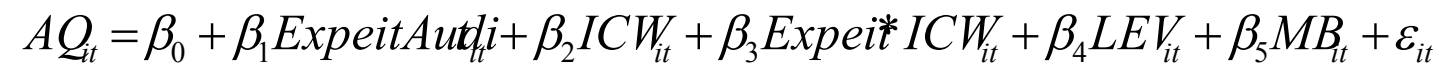

Chow (1960) introduced a test that is used to choose between integration models and the model panel. The assumptions of this model are:

$H_{0}=$ All width of the origin are equal (Pooled Model)

$H_{1}=$ At least, is different one width of the origin to the rest (Fixed effects model)

Table 15 shows the results of these tests indicate reject the null hypothesis and necessity using of panels for this group of data.

Table 15: Chow Test Results

\begin{tabular}{cc}
\hline $\boldsymbol{P}-$ Value & Test statistic \\
\hline $0.0001^{\star \star \star}$ & 4.008 \\
\hline
\end{tabular}

${ }^{* * *}$ Significance level $=5 \%$

In the panel data was used the Hausman test statistic. The assumptions of this model are:

$H_{0}=$ Random effects model

$H_{1}=$ Fixed effects model

To determine whether using of panel data to estimate the model is efficient or not, $\mathrm{F}$ Limer test and to determine which method (fix effects and or accidental effects) is more suitable, Hasman test is used. Table 16 shows the results of the Hausman test, that null hypothesis is rejected and selected fixed effects model.

Table 16: Hausman Test Results

\begin{tabular}{cc}
\hline $\boldsymbol{P}$-Value & Test statistic \\
\hline $0.0001^{* * *}$ & 28.443 \\
\hline
\end{tabular}

\footnotetext{
${ }^{* * *}$ Significance level $=5 \%$
}

Table 17 show the coefficient of determination $r^{2}, r^{2}$ adjusted. And the coefficient of determination indicates that the changes caused by regression to allocated what percentage of the total variance. Significant test model is as follows:

$H_{0}=$ The model was not significant

$H_{1}=$ The model was significant 
Table 17: The Results of Model Fitting

\begin{tabular}{cccc}
\hline $\boldsymbol{P}-$ Value & F index & $\boldsymbol{r}^{2}$ fitting & $\boldsymbol{r}^{2}$ \\
\hline $0.0001^{* * *}$ & 92.866 & 0.4797 & 0.4850
\end{tabular}

Significance level $=5 \%$

Table 18 show that this test is performed using P-Value is calculated for each factor. So that if P-Value is less than $\alpha$ be a significant factor, and if $P$-Value is greater than $\alpha$ the coefficient is not significant.

$\left\{H_{0}: \beta_{i}=0\right.$

$\left\{H_{1}: \beta_{i} \neq 0\right.$

Table 18: The Results of Regression Model

\begin{tabular}{cccccc}
\hline Variable & T Index & standard deviation & Value & T index & P Value \\
\hline Fixed effects model & $\beta_{0}$ & 1.443 & 26.628 & 18.448 & $0.0001^{* * *}$ \\
\hline Expeit Audit & $\beta_{1}$ & 1.077 & 4.027 & 3.738 & $0.0001^{* * *}$ \\
\hline ICW & $\beta_{2}$ & 1.198 & -2.977 & -2.486 & $0.013^{* * *}$ \\
\hline Expeit Audit*ICW & $\beta_{3}$ & 1.451 & 0.245 & 0.169 & 0.866 \\
\hline LEV & $\beta_{4}$ & 1.251 & -31.882 & -25.489 & $0.0001^{* * *}$ \\
\hline MB & $\beta_{5}$ & 0.214 & 1.028 & 4.797 & $0.0001^{* * *}$ \\
\hline
\end{tabular}

${ }^{* * *}$ Significance level $=5 \%$

According to above tables' regression model is significant according to $\mathrm{F}$ statistics index and $P-$ Value. This issue indicates that the model is significant, in the following significant test was performed to determine the effect of each variable index. And model validity was determined by determination coefficient.

\section{Autocorrelation Test (Durbin-Watson)}

There are several tests to check for any Autocorrelation between that model D-W (Durbin-Watson) test is the most common. D-W numerical value is variable between 0 and 4 ; if this statistic for model estimated to be around 2 (between 1 and 3 in the state more stringent between 1.5 and 2.5) indicates the absence of autocorrelation in the model. That in this model, the numerical these statistics is nearly 2 and will be accepted assuming no autocorrelation. Table 19 show the result of D-W test.

Table 19: D-W Test Results

\begin{tabular}{rr}
\hline D-W Test & Results \\
\hline 1.799 & No Autocorrelation \\
\hline${ }^{* * *}$ Significance level $=5 \%$ & \\
\hline
\end{tabular}


Discussion - We begin with a sample of firms with internal control weaknesses, and based on industry, size, and performance, match these firms to a sample of control firms without internal control weaknesses. Our conditional log it analyses indicate that a relation exists between audit committee quality, auditor independence, and internal control weaknesses. Firms are more likely to be identified with an internal control weakness, if their audit committees have less financial expertise or, more specifically, have less accounting financial expertise and non-accounting financial expertise. They are also more likely to be identified with an internal control weakness, if their auditors are more independent. In addition, firms with recent auditor changes are more likely to have internal control weaknesses. The results of this study showed that earnings quality increases with increasing auditor industry specialization and decreases with a decrease in auditor expertise. In fact, according to the coefficient is 9.711, it can be concluded that with increments of one auditor industry specialization, earnings quality increases 9.711 unit and vice versa. In other words, auditor industry specialization can have a direct impact on significantly increase the earnings quality.

In about the first hypothesis: According to the results of this study, regression model according to statistics $F$ and $\mathrm{P}$-Value obtained is significant that this issue shows the overall impact of independent variables on the dependent variable. On the other hand, according to the model coefficient of determination that is 0.4770 . It can be concluded that about $47.70 \%$ of the variation in the dependent variable explained by the independent variables. The Durbin-Watson statistic was calculated 1.789 , as the number 2 is Therefore close there is no autocorrelation in the model. Watson camera statistic of 1.789 , which because is close number two, therefore there is no autocorrelation in the model. The regression coefficient of $b_{-} 1$ index is equal to -9.359 , and statistically is significant. $B$ _ 2 coefficient is equal to 7.082 and statistically is significant. And financial leverage control variables have a significant effect ratio of book value to market. About the second hypothesis: earnings quality decreases with increasing internal controls weakness, and vice versa. In fact, according to the coefficient is - 9.359, it can be concluded that with increments of one internal control weaknesses, earnings quality decreases 9.359 unit and vice versa. In other words, internal controls weakness could have the opposite effect and decreases the earnings quality. About the third hypothesis: with entry and increase auditor industry specialization adjusted reverse impact of internal controls Weaknesses on earnings quality and reduce their negative effects and earnings quality does not decline due to internal controls weakness. Our paper is related to several recent papers on the determinants of internal control weaknesses. The following studies confirming the results of this study.

Krishnan (2005) examines the period prior to the enactment of SOX, when internal control problems are only disclosed in 8-Ks filed by firms when changing auditors. With information collected from 8-K filings, she finds that independent audit committees and audit committees with more financial expertise are significantly less likely to be associated with the incidence of internal control problems (Ziaee, 2014). Ge and McVay (2005) and Doyle et al. (forthcoming) find that material weaknesses in internal control are more likely for firms that are smaller, less profitable, more complex, growing rapidly, or undergoing restructuring. Ashbaugh-Skaife et al. (forthcoming) find that firms with more complex operations, recent changes in organization structure, auditor resignation in the previous year, more accounting risk exposure, and less investment in internal control systems are more likely to disclose internal control deficiencies. Since an entity's internal control is under the purview of its audit (Krishnan, 2005), we investigate the relation between audit quality and internal control weaknesses. In a similar study Imam and Malek (2007) examined the relationship among ownership structure and firms' performance and dividend policy. Their research sample consisted of 201 firms for a three years period covering 2001-2003. Their results demonstrated that corporate ownership has a positive and significant effect on the firm's performance, while dividends policy is negatively affected by management ownership concentration. Al Najar (2010) investigated the relationship between ownership structure and corporate governance among non-financial firms in Jordan. They found that institutional investors care about diverse factors such as capital structure, trade risk, profitability, property structure, asset liquidity and size of the firm in their decisions around investments. Generally they prefer investments in service companies in comparison with manufacturing firms. He argues that there is no significant relationship evidenced between dividends policy and institutional investors. Al Mutari (2009) examined 80 firms listed on Kuwait Stock Exchange in a 9 year period including 2000-2008. The results of their study showed that the type of shareholders influences on firms' value, while public and individual ownership have a negative and significant impact on the firms' value. In 
addition to capital structure, dividends policy is also another factor directly affecting firm's value, he declared. Setayesh et al (2010) found that corporate governance effects on earnings smoothing. They included 383 firms listed on Tehran Stock Exchange for a period of years covering 2003-2009. Multi logistic regression was employed and it was found that different groups of corporate governance have no consistent effect on industrial groups while the independence of board of directors does not influence on earnings smoothing.

\section{CONCLUSION}

This study examined the relationship between audit quality and internal control weaknesses. After hypothesis testing determined that the audit quality of corporate financial performance has positive drug Arttbat entity. Providing auditing standards generally accepted standards Audit key role in improving audit quality and the ability to Auditors are important in the prevention and detection distortions. In addition to audit and enforce standards of care Professionals who keep the true character of the contribution of audit quality it is remarkable, competence and reputation of auditors audit process and environmental factors also impact on the quality are audited. Due to the positive and significant coefficient auditor industry specialization in the first model achieved to the conclusion that auditor industry specialization has a significant effect on earnings quality and type this effect is positive. According to the results of this study, regression model according to statistics $F$ and P-Value obtained is significant that this issue shows the overall impact of independent variables on the dependent variable. According to negative and significant coefficient of internal control weaknesses in the second model, we conclude that internal controls weakness significant effect on earnings quality and type is negative. According to negative and significant internal control weaknesses coefficient in the second model and positive and significant coefficient for this variable in the variable of auditor industry specialization, we conclude that auditor industry specialization moderated impact of internal controls on Weaknesses on earnings quality. In other words, with entry and increase auditor industry specialization adjusted reverse impact of internal controls Weaknesses on earnings quality and reduce their negative effects and earnings quality does not decline due to internal controls weakness. Finally, we concluded that poor earnings quality is significantly and incrementally associated with higher information asymmetry. Specifically, the magnitude of the association between earnings quality and information asymmetry is estimated to be more than twice as large for small firms as compared to large firms.

\section{REFERENCES}

Al-Najjar, B. 2010, "Corporate governance and institutional ownership: evidence from Jordan, Corporate Governance", The international journal of business in society, 10(2), $176-190$.

Al Mutairi, M. E., Tian, G. G. \& Tan, A. 2009, "Corporate Finance Practice in Kuwait: A Survey to Confront Theory with Practice", 22nd Australasian Finance and Banking Conference.

Bhattacharya, N., Desai, H. \& Venkataraman, K. 2013, “Does Earnings Quality Affect Information Asymmetry? Evidence from Trading Costs". Journal of Contemporary Accounting Research, 30: 482-516.

Caskey, J. \& Hanlon, M. 2005, “Do dividends indicate honesty? The relation between dividends and the quality of earnings", working paper, University of Michigan, Ann Arbor, MI.

Chen, S., Shevlin, T. \& Tong, Y. 2007, "Does the pricing of financial reporting quality change around dividend changes", Journal of Accounting Research, 45(1), 1-40.

Dechow, P. \& Dichev, I. 2002, "The quality of accruals and earnings: the role of accrual estimation errors", The Accounting Review, Vol. 77, s-1, pp. 35-59.

Diamond, D., \& R. Verrecchia. 1991, “Disclosure, liquidity and the cost of capital”. Journal of Finance. 46 (4): $1325-359$.

Febriela, S. \& Sylvia V. S., "2014," Dividend payment and earnings quality: evidence from Indonesia, International Journal of Accounting and Information Management, Vol. 22 Iss: 2, pp.103 - 117.

Francies, I., Lafond, R., Olsson, P. \& Schipper, K. 2005, "The market pricing of accruals quality", journal of accounting and economics, 39(2), 295-327.

Foster, N. 2003, "The FASB and the Capital Markets". The FASB Report. Norwalk, CT: FASB. 
Kim, O., \& R. E. Verrecchia. 1994, "Market liquidity and volume around earnings announcements". Journal of Accounting and Economics. 17 (1): 41-67.

Krishnan, J. 2005, “Audit Committee Quality and Internal Control: An Empirical Analysis”, the Accounting Review, Vol. 80 (2), 649-675.

Jamei, N, \& Khedri, N. 2016, "Investigation of the relationship between Corporate Governance, Earnings Management and Tax management in Tehran stock exchange", International Journal of Humanities and Cultural Studies, v 3 (2), p 2073-2081.

Ge, W, \& McVay, S. 2005, "The Disclosure of Material Weaknesses in Internal Control after the Sarbanes-Oxley Act". Accounting Horizons, 19 (3), 137-158.

Hanlon, M., Myers, J. \& Shevlin, T. 2007, "Are dividends informative about future earnings", working paper, University of Washington, Seattle, WA.

Hassan, S. U. 2013, "Financial Reporting Quality, Does Monitoring Characteristics Matter? An Empirical Analysis of Nigerian Manufacturing Sector", The Business \& Management Review, 3(2): 147-161.

Imam, M. O., \& Malik, M. 2007, "Firm Performance and Corporate Governance through Ownership Structure: Evidence from Bangladesh Stock Market”, International Review of Business Research Papers, 3(4), 88-110.

Lambert, R., Leuz, C. \& Verrecchia, R. E. 2007, "Accounting Information, Disclosure, and the Cost of Capital”, Journal of Accounting Research, 45: 385-420.

Poorheidari, O, \& Borhaninejad, 2012, "The impact of corporate governance features on tax management of companies listed on the Tehran Stock Exchange", Auditing Knowledge, 49, 1-18.

Rajgopal, S., \& M. Venkatachalam. 2011, "Financial reporting quality and idiosyncratic volatility over the last four decades", Journal of Accounting and Economics, 51 (1-2): 1-20.

Setayesh, M. H, Ghorbani, A. \& Golmohammadi, M, 2010, "Surveying the effect of corporate governance on smoothing the earnings of companies listed in Tehran stock exchange", Audit Researches. 2(7): 34-51

Shirinbakhsh, Sh, \& Hassan Khansari, Z. 2005, "Eviews applications in econometrics”, Economic Affairs Research Institute, Tehran.

Tong, Y.H. \& Miao, B. 2011, “Are dividends associated with the quality of earnings”, Accounting Horizons, 25(1), $183-205$.

Ziaee, M., 2014, "The effect of audit quality on the performance of listed companies in Tehran Stock Exchange", International Letters of Social and Humanistic Sciences, 21, 36-43. 